\section{Increasing macrocephaly in a neonate}

Ashley M. Groves, MB, BS; Justin J. Cross, $M B, B S$; Thida Win, $M B, B S$; and Deirdre Wright, $M B, B S$

Infantile macrocephaly has a myriad of causes including megalencephaly, intracranial mass, and CSF disturbance. ${ }^{1}$

An 8-week-old infant presented with increasing head circumference. Antenatal ultrasound was unremarkable, with biparietal diameter and head circumference on the 50th centile at 20 weeks' gestation. At birth, head circumference was on the 90th centile; no other abnormalities were recognized. By 8 weeks, the child had clinical macrocephaly. The head circumference was on the 99 th centile with an abnormal cranial posture and lower limb hypotonia. MRI at 4 months showed a small foramen magnum with impingement on the cervical cord without cord signal abnormality or syrinx formation (figure, A). Radiographs (figure, B and C) were performed and the diagnosis of achondroplasia confirmed. The infant underwent neurosurgical referral and is at present subject to 6-monthly reviews. It is of note that cervical impingement in patients with achondroplasia usually presents at an older age, but its occurrence has been reported shortly after birth. ${ }^{2}$

Achondroplasia is a skeletal dysplasia with easily recognizable clinical and radiologic features, which, if missed, may lead to avoidable complications. ${ }^{2}$

1. Barkovich AJ, ed. Pediatric neuroimaging. 2nd ed. Philadelphia: Lippincott-Raven, 1996.

2. Gordon N. The neurological complications of achondroplasia. Brain Dev 2000;22:3-7.

From the Department of Radiology (Drs. Groves and Cross), and Department of Medicine (Dr. Win), Addenbrooke's Hospital, Cambridge University Teaching Hospitals Trust, and Luton and Dunstable Hospital (Dr. Wright), Luton, UK.

Received March 15, 2003. Accepted in final form June 10, 2003.

Address correspondence and reprint requests to Dr. A. Groves, Department of Radiology, Addenbrooke's Hospital, Cambridge University Teaching Hospitals Trust, Hills Road, Cambridge CB2 2QQ, UK; e-mail: drashleygroves@hotmail.com

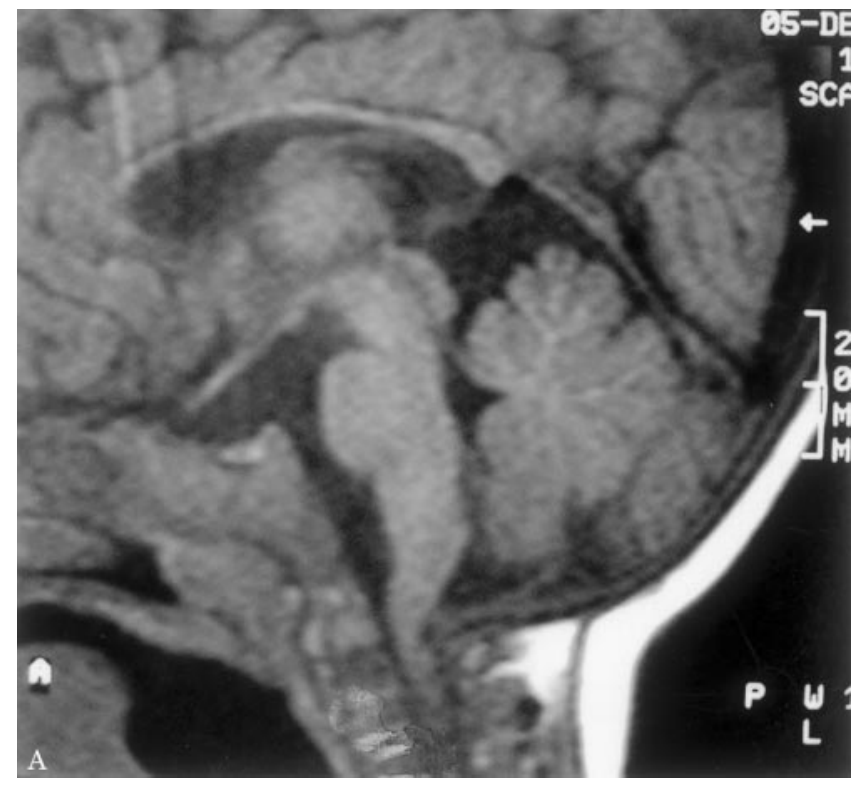

Figure A. Midsagittal T1-weighted MRI of the lower brain, showing a narrow foramen magnum, causing indentation of the cervicomedullary junction.

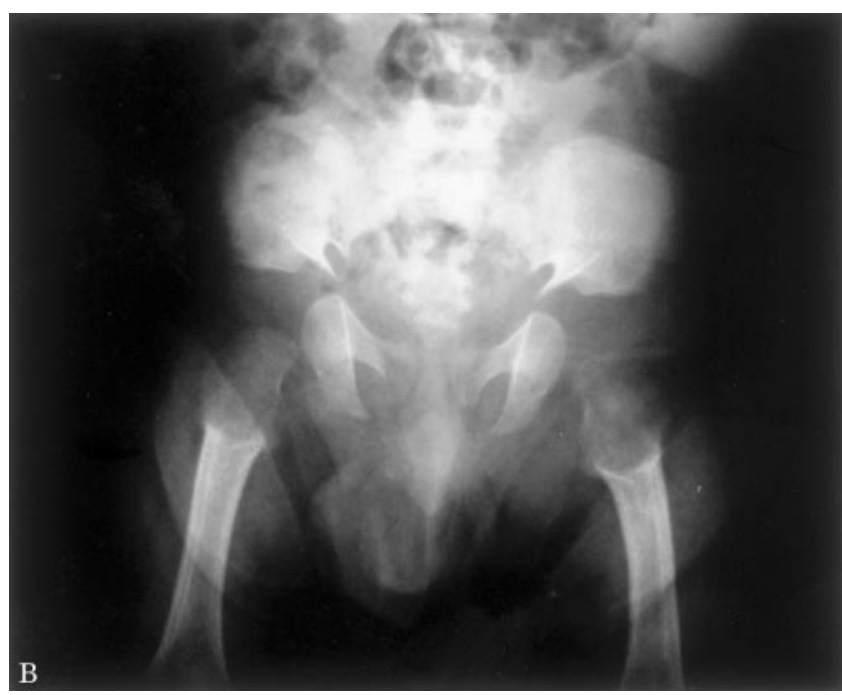

Figure B. Anteroposterior pelvic radiograph, demonstrating narrowing interpedicular distances and a "champagne glass" appearance to the pelvic floor due to square iliac bones, horizontal acetabular roofs, and narrow sciatic notches.

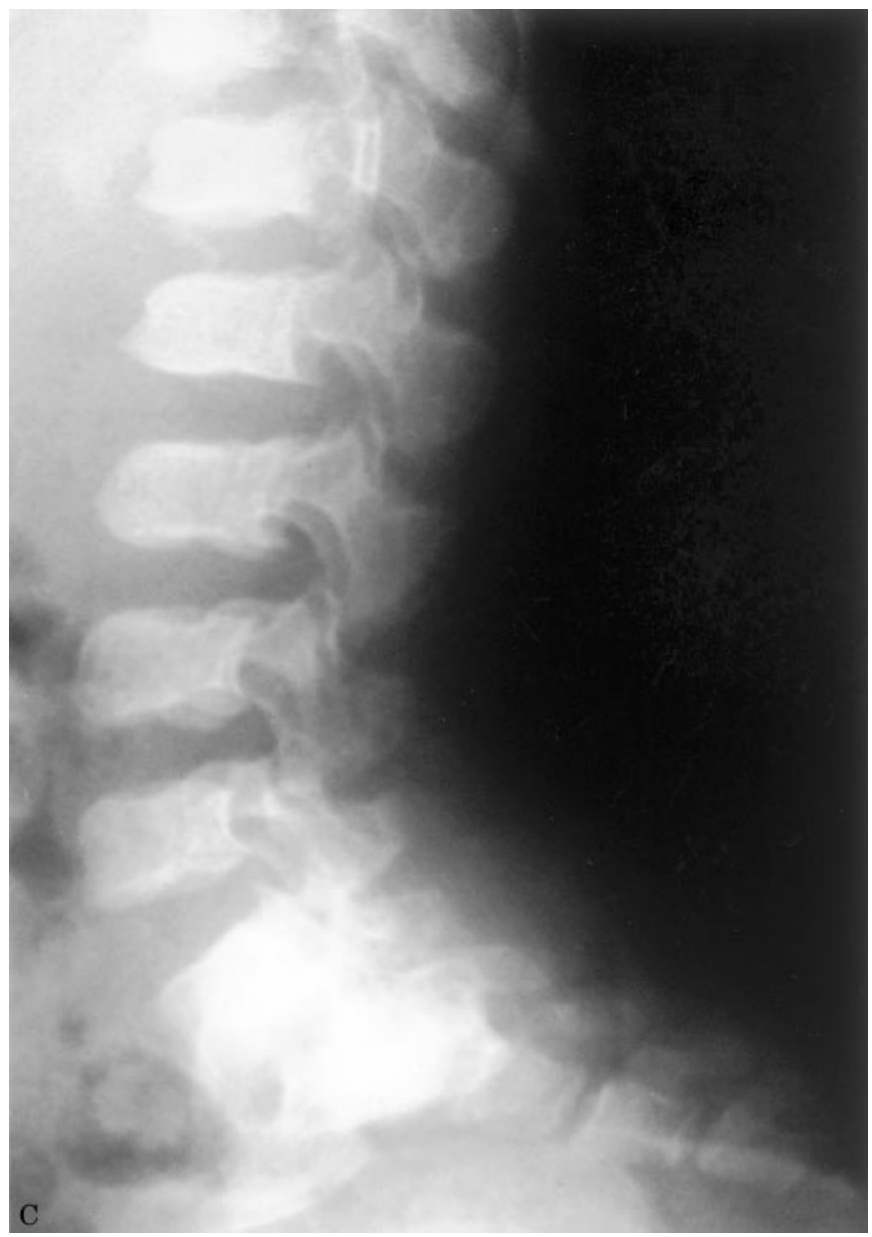

Figure C. Lateral lumbar radiograph shows sacral lordosis and anterior vertebral beaking. 


\section{Neurology}

Increasing macrocephaly in a neonate

Ashley M. Groves, Justin J. Cross, Thida Win, et al.

Neurology 2003;61;822

DOI 10.1212/01.WNL.0000085869.22589.A4

This information is current as of September 22, 2003

\section{Updated Information \&}

Services

References

Subspecialty Collections

Permissions \& Licensing

Reprints including high resolution figures, can be found at:

http://n.neurology.org/content/61/6/822.full

This article cites 1 articles, 0 of which you can access for free at: http://n.neurology.org/content/61/6/822.full\#ref-list-1

This article, along with others on similar topics, appears in the following collection(s):

All Pediatric

http://n.neurology.org/cgi/collection/all_pediatric

MRI

http://n.neurology.org/cgi/collection/mri

Neonatal

http://n.neurology.org/cgi/collection/neonatal

Information about reproducing this article in parts (figures,tables) or in its entirety can be found online at:

http://www.neurology.org/about/about_the_journal\#permissions

Information about ordering reprints can be found online:

http://n.neurology.org/subscribers/advertise

Neurology ${ }^{\circledR}$ is the official journal of the American Academy of Neurology. Published continuously since 1951, it is now a weekly with 48 issues per year. Copyright. All rights reserved. Print ISSN: 0028-3878. Online ISSN: 1526-632X.

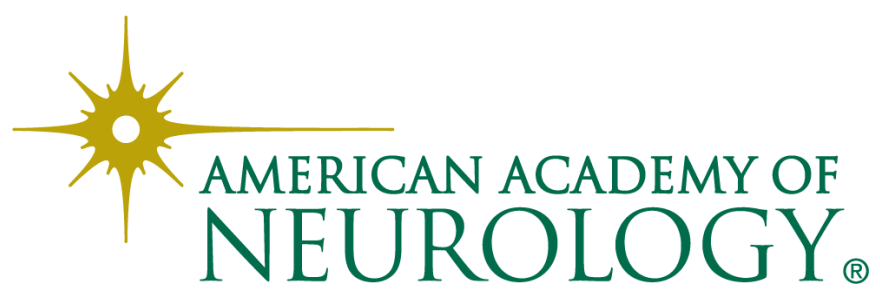

